Ambiente \& Água - An Interdisciplinary Journal of Applied Science
ISSN 1980-993X - doi:10.4136/1980-993X
www.ambi-agua.net
E-mail: ambi.agua@gmail.com

\title{
Peroxidase from green zucchini (Cucurbita pepo $L$.) immobilized on natural polymers removes phenolic compounds from water samples
}

\author{
ARTICLES doi:10.4136/ambi-agua.2226
}

Received: 27 Dec. 2017; Accepted: 10 Oct. 2018

\author{
Thâmara Machado e Silva; Aline Rodrigues dos Santos; Samantha Salomão Caramori* \\ Universidade Estadual de Goiás (UEG), Anápolis, GO, Brasil \\ Câmpus Anápolis de Ciências Exatas e Tecnológicas (CCET). \\ Laboratório de Biotecnologia. E-mail:thamaramachado.silva@gmail.com, \\ alinerodriguesdossantos3@gmail.com, sscaramori@gmail.com \\ *Corresponding author
}

\begin{abstract}
Phenolic compounds occur in effluents from a wide variety of industrial operations, and they present toxicity and generate environmental problems. The treatment of these wastes via enzyme immobilization indicates that peroxidase (E.C.1.11.1.7) is the enzyme with the widest application. In the same process, biodegradable polymers have generated significant interest from research and industrial communities. Here we applied biopolymers from sugarcane bagasse (SB) and Cerrado cashew-tree polysaccharide (PEJU-GO) as supports for peroxidase immobilization from crude green zucchini extract via physical adsorption and covalent bonding. In addition, we used these systems in the removal of phenols from industrial effluents. Electron microscopy showed a fibrous surface for SB and a microporous material for PEJUGO, characteristics that facilitate the immobilization. The infrared of both materials elucidated characteristic bands of sugars. For operational stability after 30 days of storage, the immobilized peroxidase retained 69 and 50\% activity for SB and PEJU-GO, respectively. The systems were able to remove up to $79 \%$ of phenolics from industrial wastes. Therefore, the biopolymers from sugarcane bagasse and cashew-tree polysaccharide are promising sources for biotechnology, especially when used for peroxidase immobilization. This will support enzymatic activity in laboratory practice, with homogeneous behavior in different $\mathrm{pH}$ conditions, at low cost, biodegradable, non-toxic and extracted in a sustainable way.
\end{abstract}

Keywords: biopolymers, effluents, water treatment.

\section{Peroxidase de abobrinha verde (Cucurbita pepo L.) imobilizada em polímeros naturais remove compostos fenólicos de amostras de água}

\section{RESUMO}

Os compostos fenólicos ocorrem em efluentes de uma grande variedade de processos industriais e apresentam toxicidade e geram problemas ambientais. $\mathrm{O}$ tratamento desses resíduos via imobilização de enzimas indica que a peroxidase (EC 1.11.1.7) é a enzima mais utilizada. Nos mesmos processos, polímeros biodegradáveis têm gerado grande interesse para a comunidade científica e industrial. Neste trabalho os biopolímeros de bagaço de cana-deaçúcar (BC) e o polissacarídeo de caju arbóreo do Cerrado (PEJU-GO) foram utilizados como suportes para imobilização de peroxidase de extrato bruto de abobrinha verde via adsorção

This is an Open Access article distributed under the terms of the Creative Commons Attribution License, which permits unrestricted use, distribution, and reproduction in any medium, provided the original work is properly cited. 
física e ligação covalente. Além disso, usamos esses sistemas para a remoção de fenóis de efluentes industriais. A microscopia eletrônica mostrou que BC possui uma superfície fibrosa e que PEJU-GO apresentou-se como material microporoso, características que facilitam processos de imobilização. Os espectros de infravermelho de ambos materiais elucidaram bandas características de açúcares. Para a estabilidade operacional após 30 dias de armazenamento a peroxidase imobilizada reteve 69 e 50\% de atividade para BC e PEJU-GO, respectivamente. Os sistemas foram capazes de remover até $79 \%$ de compostos fenólicos de efluentes industriais. Assim sendo, os biopolímeros de bagaço de cana-de-açúcar e do polissacarídeo de caju arbóreo do Cerrado são fontes promissoras para a biotecnologia, especialmente para a imobilização de peroxidase. Isto irá proporcionar a imobilização enzimática na prática laboratorial, com comportamento estável em diferentes condições de $\mathrm{pH}$, a custo baixo, sendo um material biodegradável, não-tóxico e extraído de forma sustentável.

Palavras-chave: biopolímeros, efluentes, tratamento de água.

\section{INTRODUCTION}

The volume of chemical pollutants is on the rise, especially textile dyes, which are stable and resistant to primary treatment methods. Since water reservoirs are affected by these and other pollutants, new remediation strategies have been developed (Choong and Focatiis, 2016).

In recent years, environmentally friendly technologies have been gradually implemented to minimize the negative impacts of industrial development on the environment, the economy and society (Darko et al., 2017). Among those products are biodegradable polymers, which have generated significant interest in research and industrial communities. The degradation of these materials, linked to their renewable sources, promotes a reduced accumulation of waste and less environmental stress, and they are more easily degraded throughout industrial processing (Choong and Focatiis, 2016).

In this regard, lignocellulosic materials in the form of plant biomass, such as sugarcane bagasse (Saccharum officinarum, L.) (SB), are the most abundant organic carbon complexes, mainly composed of cellulose, hemicellulose and lignin, used on a large scale in ethanol bioconversion. These materials have a high carbohydrate content, low lignin content, easy use, low cost of harvesting, transport and storage (Gouveia et al., 2009). The polysaccharide of Cerrado-arboreal cashew (Anacardium othonianum Rizz.) (PEJU-GO) is biocompatible, biodegradable and easy to obtain, and it presents a physicochemical structure in line with properties that allow technological applications (Silva et al., 2017). Moreover, due to their colloidal properties, this material and other polysaccharides have been used as thickeners, gelling agents, emulsifiers, stabilizers, binders (Bhushette and Annapure, 2017) and biodegradable polymers (Akthar and Ding, 2017).

Phenolic compounds occur in waste outflows from a wide variety of industrial operations. Almost all are toxic (Liu et al., 2002), and some are known to be carcinogenic in humans; they are incorporated in the food chain and generate important environmental problems. Some methods for phenolic removal involve the use of microorganisms, activated charcoal or chemical oxidation. However, the methods often have disadvantages, such as low efficiency, high cost or the fact that they may generate even more toxic products than the original targets.

An alternative to treat phenolic wastewater is the use of the enzyme peroxidase (E.C.1.11.1.7). Horseradish peroxidase (HRP) has been successfully used to eliminate phenol from aqueous solutions and is by far the most-researched enzyme (Kalaiarasan and Palvannan, 2013). However, due to the cost of purification, many efforts have been made to find alternative sources of this enzyme, mainly in plants. The green zucchini (Cucurbita pepo L.) has been presented as a promising source of peroxidase when compared to other fruit and vegetables, 
such as peach (Prunus pérsica, L.), manioc (Manihot utilíssima, L.) and artichokes (Cynara scolymus L.) (Vieira et al., 2003), for example. In this work, the hypothesis is that sugarcane bagasse (S. officinarum, L.) and the Cerrado-arboreal cashew polysaccharide (A. othonianum Rizz.) are capable of immobilizing peroxidase (POX) extracted from green zucchini (Cucurbita реро, L) to remove phenol from industrial effluents, in order to reduce their concentration in these environments.

\section{MATERIALS AND METHODS}

We purchased the samples of green zucchini (Cucurbita pepo, L.) and sugarcane bagasse (Saccharum officinarum, L.) in local stores in Anápolis, Goiás, Brazil, during January 2016. The gums of Cerrado-arboreal cashew (Anacardium othonianum Rizz.) were collected in the arboretum of the School of Agronomy, Federal University of Goiás, Brazil (16 $35^{\circ} 59.1^{\prime \prime}$ S, 49 $16^{\prime} 47.1^{\prime \prime}$ W) in February 2016.

The reagents ethyl alcohol P.A., pyrogallol, 35\% hydrogen peroxide, sodium phosphate monobasic, sodium meta-periodate, nitrophenol, phenol, bromophenol, catechol and FolinCiocalteu reagent were obtained from Sigma-Aldrich (USA).

\subsection{Obtaining the Green Zucchini Extract and Peroxidase Activity}

The Cucurbita pepo L. plant samples were cut, crushed in $0.1 \mathrm{~mol} \mathrm{~L}^{-1}$ monobasic sodium acetate solutions ( $\mathrm{pH} 4 ; 4.5 ; 5), 0.1 \mathrm{~mol} \mathrm{~L}^{-1}$ sodium phosphate monobasic ( $\mathrm{pH} 6 ; 6.5 ; 7 ; 7.5$ ) and $0.1 \mathrm{~mol} \mathrm{~L}^{-1}$ sodium borate $(\mathrm{pH} 8)$ in the proportion of $1: 1(\mathrm{p} / \mathrm{v})$, then filtered for use. The peroxidase activity in the green zucchini (GZP) was determined in a Kasuaki UV/VIS UV/VIS spectrophotometer Model IL-592 (Japan), using pyrogallol in $0.1 \mathrm{~mol} \mathrm{~L}^{-1}$ sodium phosphate, $\mathrm{pH}$ 6.0. Absorbance (at $420 \mathrm{~nm}$ ) was measured after 1 min of reaction. We considered the enzyme unit (U) as the amount of peroxidase capable of increasing 0.1 absorbance / min of reaction under the assay conditions. To choose the best $\mathrm{pH}$ extract, we tested the data using analysis a posteriori (Tukey test), considering $\mathrm{p}<0.05$.

\subsection{Characterization of Sugarcane Bagasse and Cerrado-Arboreal Cashew}

The characterization of the polysaccharide from Cerrado-arboreal cashew (PEJU-GO) was performed according to Silva et al. (2017). To obtain PEJU-GO and SB treated with sodium periodate (PEJUp-GO and SBp, respectively), $0.05 \mathrm{~g}$ of support stirred for $30 \mathrm{~min}$ at $26^{\circ} \mathrm{C}$ with $2.0 \mathrm{~mL}$ of $0.1 \mathrm{~mol} \mathrm{~L}^{-1}$ sodium periodate solution and $10 \mathrm{~mL}$ of $0.1 \mathrm{~mol} \mathrm{~L}^{-1}$ sodium phosphate buffer $\mathrm{pH}$ 7.0. PEJU-GO was precipitated with absolute ethanol for $24 \mathrm{~h}$. After discarding the supernatant, both PEJUp-GO and SBp were dried at room temperature and the powder kept in amber flasks at $4^{\circ} \mathrm{C}$ for use.

The morphological analysis of the polymers (PEJU-GO, PEJU-GO, SB and SBp) was performed by scanning electron microscopy (Shimadzu, model SSx 550, Japan), with magnification from 50 to 1000. The polymers (PEJU-GO, PEJUp -GO, SB and SBp) were analyzed in infrared spectrometry with $\mathrm{KBr}$ pellets (Bomn FT-IR model MB100, USA) and the scanning performed in the range of 4000 to $500 \mathrm{~cm}^{-1}$. We compared the spectra to characterize the chemical groups present in the samples, according to the literature.

We evaluated the thermal stability of PEJU-GO, PEJU-GO, SB and SBp by thermogravimetric analysis. The samples were subjected to heating ramps of $25^{\circ} \mathrm{C}$ at $500^{\circ} \mathrm{C}$, at a rate of $10^{\circ} \mathrm{C} \mathrm{min}^{-1}$, using DTG-60H (Shimadzu, China).

\subsection{Tests of Immobilization of Peroxidase from Crude Extract of Green Zucchini}

The immobilization of GZP was performed in PEJU-GO and SB by physical adsorption and covalent binding using sodium periodate, and the supports were identified as PEJUp-GO and $\mathrm{SBp}$, respectively. 
The tests for the best retention of enzyme activity at different concentrations of enzyme and support, immobilization $\mathrm{pH}$, storage and reuse days were conducted using $1000 \mu \mathrm{L}$ GZP (270 U) in $10 \mathrm{mg}$ PEJU-GO, $20 \mathrm{mg}$ PEJUp-GO, $2.5 \mathrm{mg}$ of SB and $15 \mathrm{mg}$ SBp under gentle agitation (720 rpm) for $2 \mathrm{~h}$ at $4^{\circ} \mathrm{C}$.

For the method of physical adsorption, the immobilization in PEJU-GO used $1000 \mu \mathrm{L}$ of the crude GZP extract ( $270 \mathrm{U}$ ) (obtained by milling the plant samples in $0.1 \mathrm{~mol} \mathrm{~L}^{-1}$ sodium phosphate buffer solution and $\mathrm{pH} 7.0$ ), allowed to react with $10 \mathrm{mg}$ of the support under gentle agitation $(720 \mathrm{rpm})$ for $2 \mathrm{~h}$ at $4^{\circ} \mathrm{C}$. A control group was made using only $0.1 \mathrm{~mol} \mathrm{~L}^{-1}$ sodium phosphate buffer solution $\mathrm{pH} 7.0$ and the support, without adding enzyme. The PEJU-GO-GZP complex was precipitated with ice-cold absolute ethanol, centrifuged and assayed for immobilized enzymatic activity. The same procedure was performed for immobilization by physical adsorption in SB, including the control group. $1000 \mu \mathrm{L}$ of crude GZP extract (270 U) were allowed to react with $2.5 \mathrm{mg} \mathrm{SB}$ under gentle stirring $(720 \mathrm{rpm})$ for $2 \mathrm{~h}$ at $4^{\circ} \mathrm{C}$.

For the immobilization tests by covalent bonding, the supports were activated with sodium periodate as described in 2.2. After the activated substrates, $1000 \mu \mathrm{L}$ of the crude GZP extract $(270 \mathrm{U})$ were allowed to react with $20 \mathrm{mg}$ PEJU-GO under gentle agitation $(720 \mathrm{rpm})$ for $2 \mathrm{~h}$ at $4{ }^{\circ} \mathrm{C}$. A control group was made using only sodium phosphate buffer solution, $0.1 \mathrm{~mol} \mathrm{~L}^{-1} \mathrm{pH}$ 7.0, and support. Then, the PEJUp-GO-GZP complex was precipitated with ice-cold absolute ethanol, centrifuged and assayed for immobilized enzymatic activity. The same procedure was performed for immobilization in SBp, including the control group. $1000 \mu \mathrm{L}$ of crude GZP extract $(270 \mathrm{U})$ were allowed to react with $15 \mathrm{mg}$ of SB under gentle agitation $(720 \mathrm{rpm})$ for $2 \mathrm{~h}$ at $4^{\circ} \mathrm{C}$.

The enzyme activity test consisted of adding to the immobilized GZP complex $1.4 \mathrm{~mL}$ of $0.1 \mathrm{~mol} \mathrm{~L}{ }^{-1}$ sodium phosphate buffer, $\mathrm{pH} 6.0,0.5 \mathrm{~mL}$ of $0.05 \mathrm{~mol} \mathrm{~L}^{-1}$ hydrogen peroxide and $1.0 \mathrm{ml}$ of $0.07 \mathrm{~mol} \mathrm{~L}^{-1}$ pyrogallol. After $1 \mathrm{~min}$ of reaction the reading was performed according to Item 2.1 .

\subsection{Potential use of free and immobilized peroxidase for degradation of phenolic compounds}

The tests with phenolic compounds and industrial effluents (WTS and Textiles) were carried out based on the methodology of Ramalho et al. (2016). The effluent samples were collected at the Waste Treatment Station (WTS) of the Agribusiness District of Anápolis (DAIA) $\left(16^{\circ} 30^{\prime} \mathrm{S}\right.$ and $\left.49^{\circ} 00^{\prime} \mathrm{W}\right)$ and at a textile corporation, Cia Hering of São Luís dos Montes Belos, Goiás (16 $52^{\prime} \mathrm{S}$ and $\left.50^{\circ} 32^{\prime} \mathrm{W}\right)$. The organic load contained in the raw sewage, according to the Department of the Environment of the DAIA, is $3.750 \mathrm{~kg}$ BOD.day ${ }^{-1}$.

We incubated the free GZP and the PEJU-GO-GZP, PEJUp-GO-GZP, SB-GZP and SBpGZP complexes with pyrogallol, catechol, phenol, bromophenol, and nitrophenol (1.0 $\mathrm{mol} \mathrm{L}^{-1}$, initial concentration). We performed the same procedure replacing the phenolic compounds with the crude effluent (WTS at $0.1 \mathrm{~mol} \mathrm{~L}^{-1}$ and Textiles at $0.2 \mathrm{~mol} \mathrm{~L}^{-1}$ ). We then evaluated the capacity of immobilized complexes to remove phenols from the effluent samples using timedependent kinetics ranging from $10 \mathrm{~min}$ to $420 \mathrm{~min}$. The residual phenol concentration was monitored as in Ramalho et al. (2016). We used the immobilized complexes obtained through physical adsorption, since they presented better immobilization conditions.

\section{RESULTS AND DISCUSSION}

Figure 1 shows the enzymatic activities at different extraction $\mathrm{pH}$. The optimum $\mathrm{pH}$ for peroxidases of crude extracts varies according to the inherent characteristics of the enzyme itself, the composition of plant isoenzymes in the crude extract and the choice of substrate (Ramalho et al., 2016). The differences in the mean values among the treatment groups are not 
great enough to exclude the possibility that the difference is due to random sampling variability; there is not a statistically significant difference $(p=0.824>0.05)$. We chose the maximum mean value (44.1U), obtained when $0.1 \mathrm{~mol} \mathrm{~L}^{-1}$ sodium phosphate buffer, $\mathrm{pH} 7.0$ was used to define the extraction $\mathrm{pH}$ for the subsequent tests.

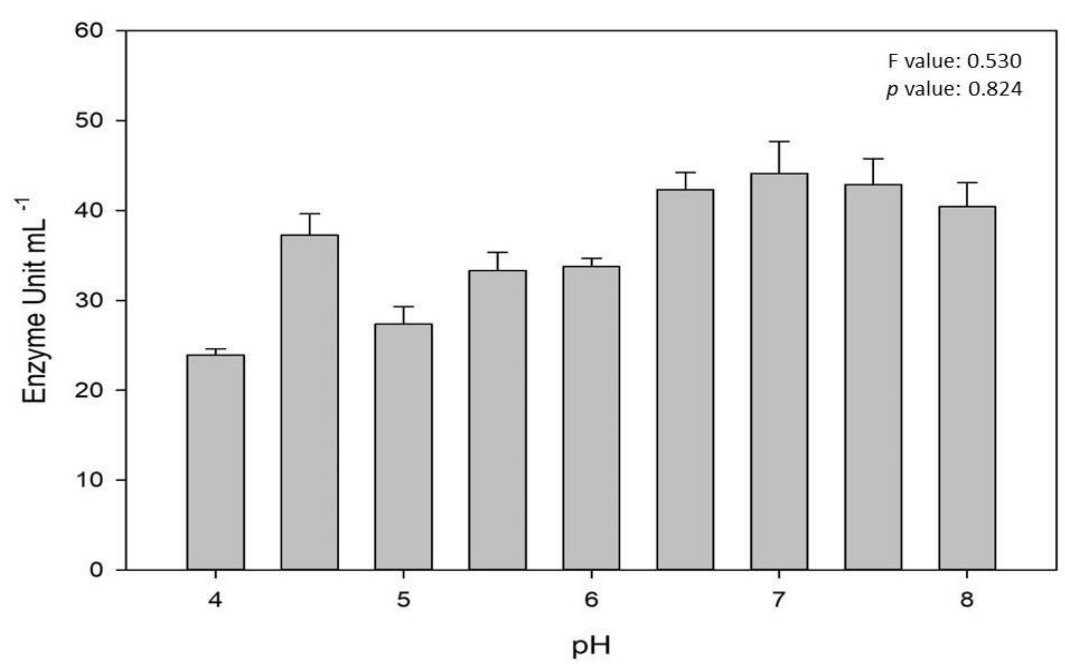

Figure 1. Activity of green zucchini peroxidase (Cucurbita pepo, L.) in different extraction $\mathrm{pH}$ values. The extracts were obtained from monobasic sodium acetate $0.1 \mathrm{~mol} \mathrm{~L}^{-1}(\mathrm{pH} 4 ; 4.5 ; 5), 0.1 \mathrm{~mol} \mathrm{~L}^{-1}$ sodium phosphate monobasic $(\mathrm{pH} 6 ; 6.5 ; 7 ; 7.5)$ and $0.1 \mathrm{~mol} \mathrm{~L}^{-1}$ sodium borate $(\mathrm{pH} 8)$ at the proportion of $1: 1(\mathrm{p} / \mathrm{v})$.

Source: Prepared by the author.

\subsection{Characterization of Sugarcane Bagasse and Cerrado-Arboreal Cashew}

Figure 2 shows the morphological aspects obtained by scanning electron microscopy of SB (2A), SB-p (2B), PEJU-GO (2C) and PEJUp-GO (2D), respectively.
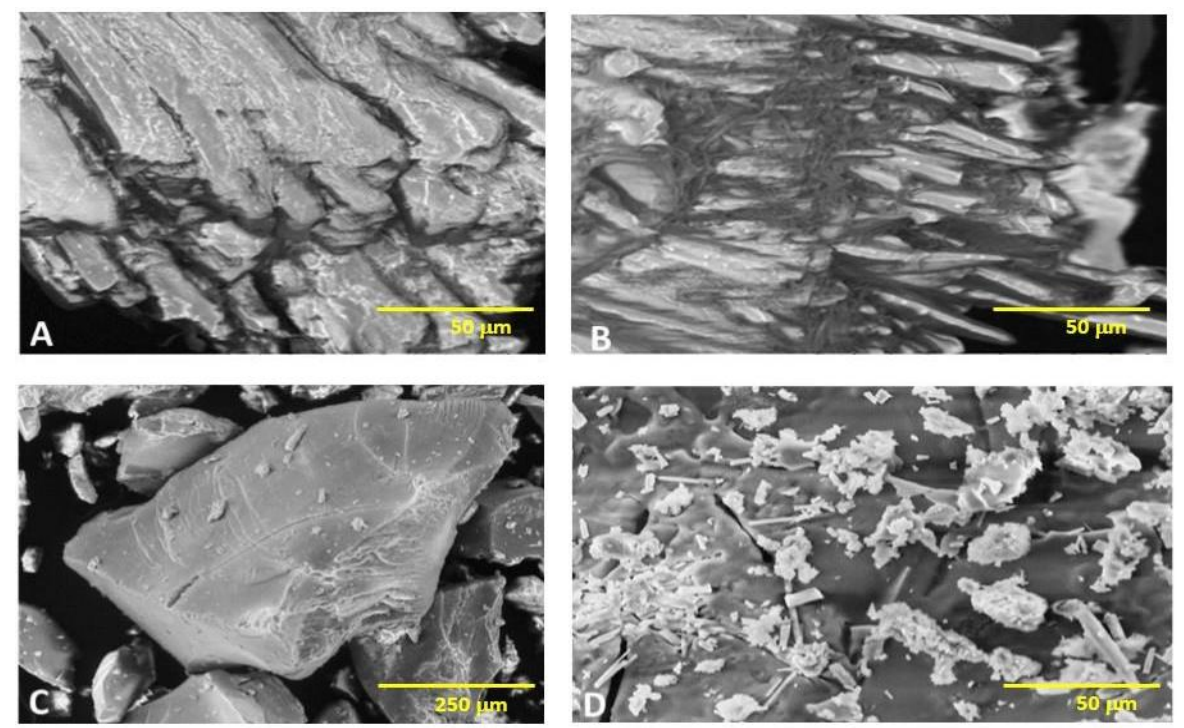

Figure 2. Electron micrograph of crude sugarcane bagasse (Saccharum officinarum, L.) (A), sugarcane bagasse treated with sodium periodate (B), crude Cerrado-arboreal polysaccharide (Anacardium othonianum Rizz.) (C) and Cerrado-arboreal polysaccharide treated with sodium periodate (D) at 1000x and 1500x, respectively.

Source: Prepared by the author. 
Figure 2A shows a fibrous aspect with bundles of microfibrils as also demonstrated by Kristiansen et al. (2010). The SBp (Figure 2B) presented a rupture of these microfibrils, characteristic of the treatment of sodium periodate in sugars. The PEJU-GO (Figure 2C) had a porous, irregular and crystalline surface, with an extensive and amorphous mass, reliefs and depressions. This can favor the application of this material in biotechnological processes, such as enzyme immobilization, because it allows adhesion to and stability of the immobilized complex. In the present study, PEJUp-GO had characteristic aspects for the sodium periodatetreated polysaccharides: irregular fragments, amorphous and dispersed mass (Kristiansen et al., 2010).

Infrared spectra of SB and SBp (Figure 3A) showed characteristic bands of lignocellulosic fibers. The strongest peaks occurred at 3428 and $1048 \mathrm{~cm}^{-1}$, characterizing stretches of $\mathrm{OH}$ and $\mathrm{COH}$ groups, respectively. There was the appearance of bands between 2918 and $2850 \mathrm{~cm}^{-1}$, characteristic of the hemicellulose spectrum. The sugarcane bagasse treated with sodium periodate (Figure 3A) showed bands close to 1740 and $880 \mathrm{~cm}^{-1}$, with a strong peak at $1728 \mathrm{~cm}^{-1}$, as observed in carbonyl groups (Calvini et al., 2006). In addition, when the oxidation degree was higher, the bands in cellulose periodate appeared near to 1740 and $880 \mathrm{~cm}^{-1}$ (Calvini et al., 2006). For the PEJU-GO (Figure 3B), we found polysaccharide bands, such as at 3000 to $2840 \mathrm{~cm}^{-1}$ (OH stretch). The bands present in the range of 1870 to $1540 \mathrm{~cm}^{-1}$ are related to the presence of $\mathrm{C}=\mathrm{O}$ groups (Kristiansen et al., 2010). For PEJU-GO (Figure 3B) there were absorptions between 1600 and $1500 \mathrm{~cm}^{-1}$ corresponding to amide Group I $(\mathrm{C}=\mathrm{O})$ and $\mathrm{N}-\mathrm{H}$ amine bond vibrations, respectively. The spectrum showed high intensity absorption at $1736 \mathrm{~cm}^{-1}(\mathrm{C}=\mathrm{O})$, indicating the oxidation of PEJUp-GO. The approximate absorbance of $1740 \mathrm{~cm}^{-1}$ is characteristic of carbonyl groups, whereas the $880 \mathrm{~cm}^{-1}$ range is generally attributed to the formation of hemiacetal bonds between the aldehyde groups and neighboring hydroxyl groups (Calvini et al., 2006).
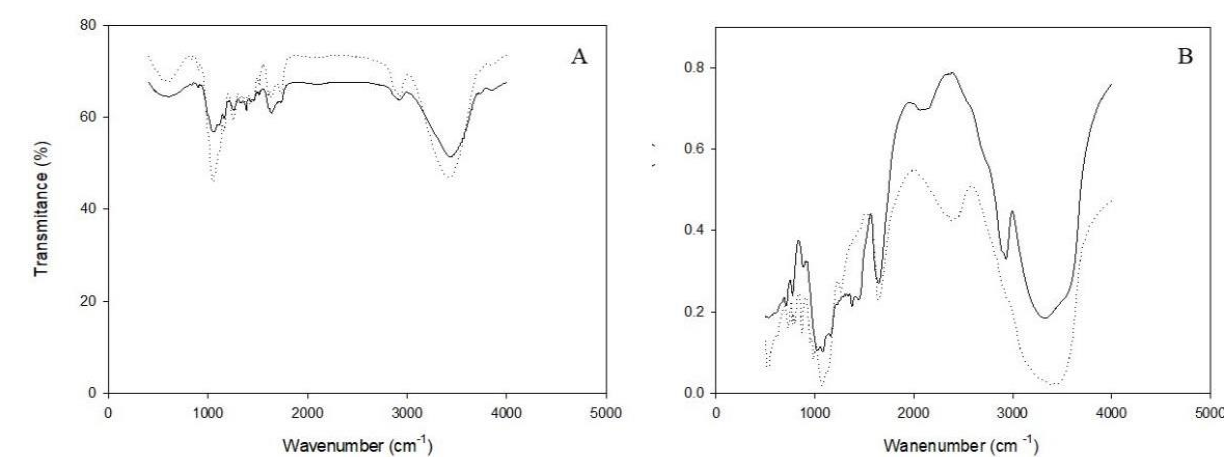

Figure 3. Infrared spectra of crude sugarcane bagasse (Saccharum officinarum, L.) and treated with sodium periodate (A) and polysaccharide from Cerrado-arboreal cashew (Anacardium othonianum Rizz.), crude and treated with sodium periodate (B), respectively. The full rows represent both sugarcane bagasse and crude polysaccharide. The dashed lines represent the two polymers treated with sodium periodate. Samples were analyzed with $\mathrm{KBr}$ pellets (Bomn FT-IR model MB100, USA) and scanned in the range of 500 to $4000 \mathrm{~cm}^{-1}$.

Source: Prepared by the author.

The evaluation of the thermal stability of the polymers is in Figure 4. For the SB (Figure $4 \mathrm{~A}$, full line) decomposition occurs at two peaks: $338^{\circ} \mathrm{C}$ and $480^{\circ} \mathrm{C}$. For SBp (Figure $4 \mathrm{~A}$, dashed line) decomposition occurred at $334^{\circ} \mathrm{C}$ and $450^{\circ} \mathrm{C}$ due to exposure of the sugars after treatment with sodium periodate, because of the chemical modification on the fibers. 

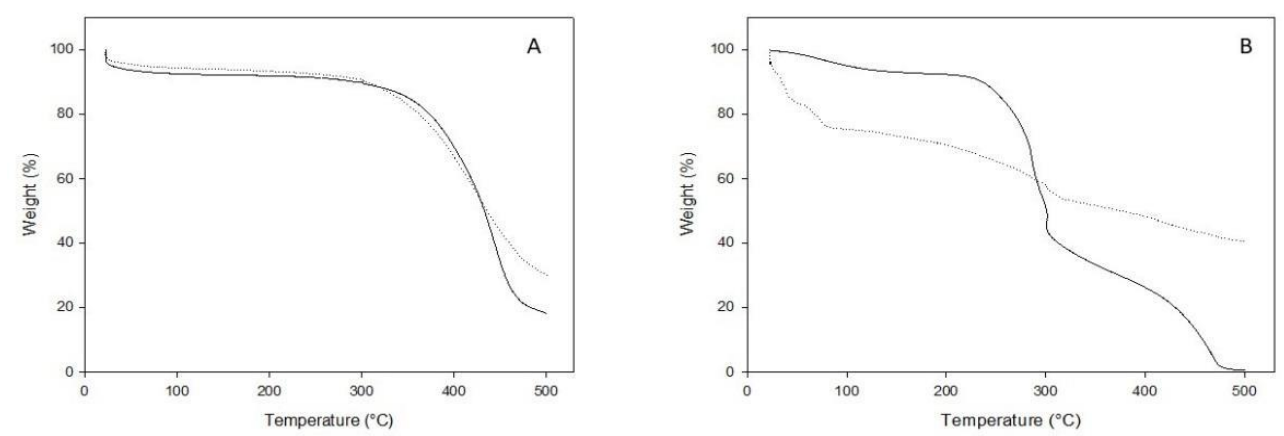

Figure 4. Thermogravimetry of Saccharum officinarum, L. crude and treated with sodium periodate (A) and Cerrado-arboreal cashew polysaccharide (Anacardium othonianum Rizz.), crude and treated with sodium periodate (B), respectively. The full rows represent the sugarcane bagasse and the crude cashew polysaccharide. The dotted lines represent the polymers treated with sodium periodate. Samples were heated at $25^{\circ} \mathrm{C}$ to $500^{\circ} \mathrm{C}$ at the rate of $10^{\circ} \mathrm{C} \mathrm{min}{ }^{-1}$ using DTG-60H (Shimadzu, China).

Source: Prepared by the author.

The thermal decomposition of PEJU-GO found by Silva et al. (2017) (Figure 4B, full line) was at 280 and $300^{\circ} \mathrm{C}$ (first stage) and between 300 and $490^{\circ} \mathrm{C}$ (second stage). For PEJUp-GO (Figure $4 \mathrm{~B}$, dashed line) the decomposition occurs between $50^{\circ} \mathrm{C}$ and $100^{\circ} \mathrm{C}$ (maximum at $80^{\circ} \mathrm{C}$ ). This finding is in accordance with the characteristic of sugar chain disruption caused by sodium periodate, starting decomposition of the carbon skeleton earlier than the crude polysaccharide. The second peak was observed between 320 and $500^{\circ} \mathrm{C}$ (maximum at $500^{\circ} \mathrm{C}$ ), probably due to the depolymerization of $\mathrm{CO}$ and $\mathrm{CH}_{4}$ bonds. Degradation of the sodium periodate-treated polysaccharide occurs initially at mild temperatures, since oxidation may decrease the interactions (electrostatic forces, hydrogen bonds and van der Waals forces) among the biopolymers. Both polymers behave in a stable manner along a temperature gradient, which, for an industrial application, guarantees the stability of the support and the effective and stable conduction of the process at high temperatures.

\subsection{Immobilization of Peroxidase from Green Zucchini Crude Extract}

The activity of GZP used for the immobilization reactions via physical adsorption (in SB and PEJU-GO) and covalent binding (in SBp and PEJUp-GO) was $270 \mathrm{U}$. The best immobilization conditions for sugarcane bagasse and Cerrado-arboreal polysaccharide are in Table 1.

The physical, chemical and morphological modifications on the supports, by the application of additives (in this case sodium periodate), produce immobilized biocatalysts with greater catalytic efficiency due to the minimization of the diffusion effects of substrates and products during reaction, besides the improvement of the operational stability in several processes (Niu et al., 2013). In this aspect, both SB and PEJU-GO were more efficient via physical adsorption than in covalent binding, since all systems demonstrated versatility and stability in the two immobilization tested routes.

For the GZP-SB and GZP-SBp complexes, the physical adsorption method allowed the retention of $100 \%$ of the enzymatic activity, followed by $75 \%$ by covalent binding, respectively. This yield is remarkable due to the structure presented through electron microscopy and the infrared spectrum, showing functional groups capable of allowing the union of the enzyme with the support, through electrostatic attractions established between the opposing charges that are present both on the surface of the support (for the cane bagasse, fibrous and with relief) and the enzyme. In the case of physical adsorption, the enzymes are bound to the matrix through electrostatic and hydrophobic interactions (Silva et al., 2017). 
Table 1. Optimal conditions for immobilized GZP in sugarcane bagasse (Saccharum officinarum, L.) and in Cerrado-arboreal cashew polysaccharide (Anacardium othonianum Rizz.) via physical adsorption and covalent binding.

\begin{tabular}{|c|c|c|c|c|}
\hline \multirow[t]{2}{*}{ Parameters } & \multicolumn{2}{|c|}{ Sugarcane bagasse } & \multicolumn{2}{|c|}{ Cerrado cashew polysaccharide } \\
\hline & Adsorption & Covalent binding & Adsorption & Covalent binding \\
\hline & SB & SBp & PEJU-GO & PEJUp-GO \\
\hline $\begin{array}{l}\text { Offered support } \\
(\mathrm{mg})\end{array}$ & 2.5 & 15 & 10 & 20 \\
\hline $\begin{array}{l}\text { Offered GZP } \\
\qquad(\mu \mathrm{L})\end{array}$ & 1000 & 1000 & 1000 & 1000 \\
\hline $\begin{array}{c}\text { Immobilization } \\
\mathrm{pH}\end{array}$ & $5.0 ; 7.0$ & $5.0 ; 7.0$ & 7 & $5.0 ; 7.0$ \\
\hline $\begin{array}{c}\text { Immobilization } \\
\text { time }(\mathrm{h})\end{array}$ & $2 \mathrm{~h}$ & $1 \mathrm{~h}$ & $2 \mathrm{~h}$ & $2 \mathrm{~h}$ \\
\hline Repeated use & $\begin{array}{c}8 \text { cycles, } 28 \% \\
\text { remaining enzyme } \\
\text { activity }\end{array}$ & $\begin{array}{l}8 \text { cycles, } 47 \% \\
\text { remaining enzyme } \\
\text { activity }\end{array}$ & $\begin{array}{c}7 \text { cycles, } 28 \% \\
\text { remaining enzyme } \\
\text { activity }\end{array}$ & $\begin{array}{l}8 \text { cycles, } 21 \% \mathrm{~d} \\
\text { remaining enzyme } \\
\text { activity }\end{array}$ \\
\hline Shelf life (days) & $\begin{array}{c}30 \text { days, } 69 \% \\
\text { remaining enzyme } \\
\text { activity }\end{array}$ & $\begin{array}{c}30 \text { days, } 77 \% \\
\text { remaining enzyme } \\
\text { activity }\end{array}$ & $\begin{array}{c}30 \text { days, } 50 \% \\
\text { remaining enzyme } \\
\text { activity }\end{array}$ & $\begin{array}{c}30 \text { days, } 60 \% \\
\text { remaining enzyme } \\
\text { activity }\end{array}$ \\
\hline
\end{tabular}

The repeated use for GZP-SBp ( 8 cycles, $28 \%$ of remaining enzyme activity) and GZPSBp ( 8 cycles, $47 \%$ of remaining enzymatic activity) indicates that those biodegradable systems are promising materials for biotechnological applications. The physical nature of the support, such as morphology, size and distribution of the beams in the structure (Figure 2A), provides an increase in immobilization efficiency caused by mass transfer between the immobilized liquid and enzyme medium (Niu et al., 2013).

The $\mathrm{pH}$ monitoring in industrial processes (feedstuffs, pharmaceuticals, water treatment and effluents) is essential for their effectiveness. The application of the GZP-SB and GZP-SBp complexes (Table 1) in industrial processes makes it possible to perform at different $\mathrm{pH}$ ranges.

After analyzing the stability of GZP-SB and GZP-SBp complexes for 30 days, we observed the maintenance of the peroxidase activity at 69 and 77\%, respectively (Table 1). The ability of SB to retain active enzymes was also identified by Ahirwar et al. (2017), using cellulase immobilized assays via covalent attachment to polystyrene pellets (77\% activity after 35 days of storage). This reinforces the understanding that SB is a promising support for enzyme immobilization with the differential of biodegradability in the environment. Under the same storage conditions, the peroxidase activity in the GZP-PEJU and GZP-PEJUp complexes remained at 50\% at the end of that period (Table 1). Niu et al. (2013) found a similar result for the same conditions in fibrous membranes. The authors suggest that the polysaccharides play fundamental roles in enzymatic stability through electrostatic, dipole-ionic or hydrophobic interactions. This is due to the chemical interactions and functional groups that are present in the support.

GZP immobilization studies in the PEJU-GO and PEJUp-GO complexes presented 100\% and $85 \%$ immobilization yield, respectively. In this context, the solubility in water presented by PEJU-GO makes this material an attractive support for enzyme immobilization, since its recovery can easily be achieved by simple precipitation with polar organic solvents, such as ethanol. This yield is justifiable due to the structure presented by electron microscopy (Figure 2C), in which the enzyme binds to the support through electrostatic attractions established between the opposing charges, both on the surface of the support (for PEJU-GO, porous and with reliefs) and on the enzyme. In addition, the total adsorption capacity of the final product is predicted as a function of the texture and chemistry of the polymer (Kristiansen et al., 2010). 
The influence of $\mathrm{pH}$ in this process is determinant and is shown in Table 1. Studies by Liu et al. (2002) reported the stabilization of the enzymatic activity of HRP in the presence of polysaccharides (such as dextran and sodium alginate), resulting in the retention of HRP activity when there are changes in $\mathrm{pH}$ and temperature. The use of polysaccharides as additives may increase catalytic efficiency by forming a protective layer at the active site of the enzyme to restrain the attack of free phenoxy radicals formed in the catalytic cycle (Kalaiarasan and Palvannan, 2013). Since PEJU-GO is able to retain HRP activity in both acidic (66\% enzymatic activity at $\mathrm{pH} 5)$ and neutral (65\% enzymatic activity at $\mathrm{pH} 7)$ conditions, this behavior allows its application in different reaction media.

Table 1 also shows the operational stability of the immobilized complexes, allowing up to seven reaction cycles with retention of $21 \%$ of the enzymatic activity. These data demonstrate the potential of support-immobilized peroxidase systems in commercial applications such as low-cost waste treatment.

\subsection{Potential use of free and immobilized POX from green zucchini crude extract (Cucurbita pepo $\mathrm{L}$.) for the degradation of phenolic compounds}

In the phenol removal tests, the immobilized enzymes were effective in the treatment of any phenolic compounds (Figure 5). The GZP-SB removed $79 \%$ of phenol from the WTS (after $120 \mathrm{~min}$ ), $19 \%$ of pyrogallol after $10 \mathrm{~min}$ and more than $90 \%$ of the textile effluent after 400 min of reaction. The GZP-PEJU complex was able to remove $59 \%$ of pyrogallol and $48 \%$ of bromophenol after $10 \mathrm{~min}$ of reaction. For the textile effluent, GZP-PEJU presented 76\% removal efficiency in $180 \mathrm{~min}$ of reaction and $93 \%$ for the industrial effluent in $420 \mathrm{~min}$ of reaction.

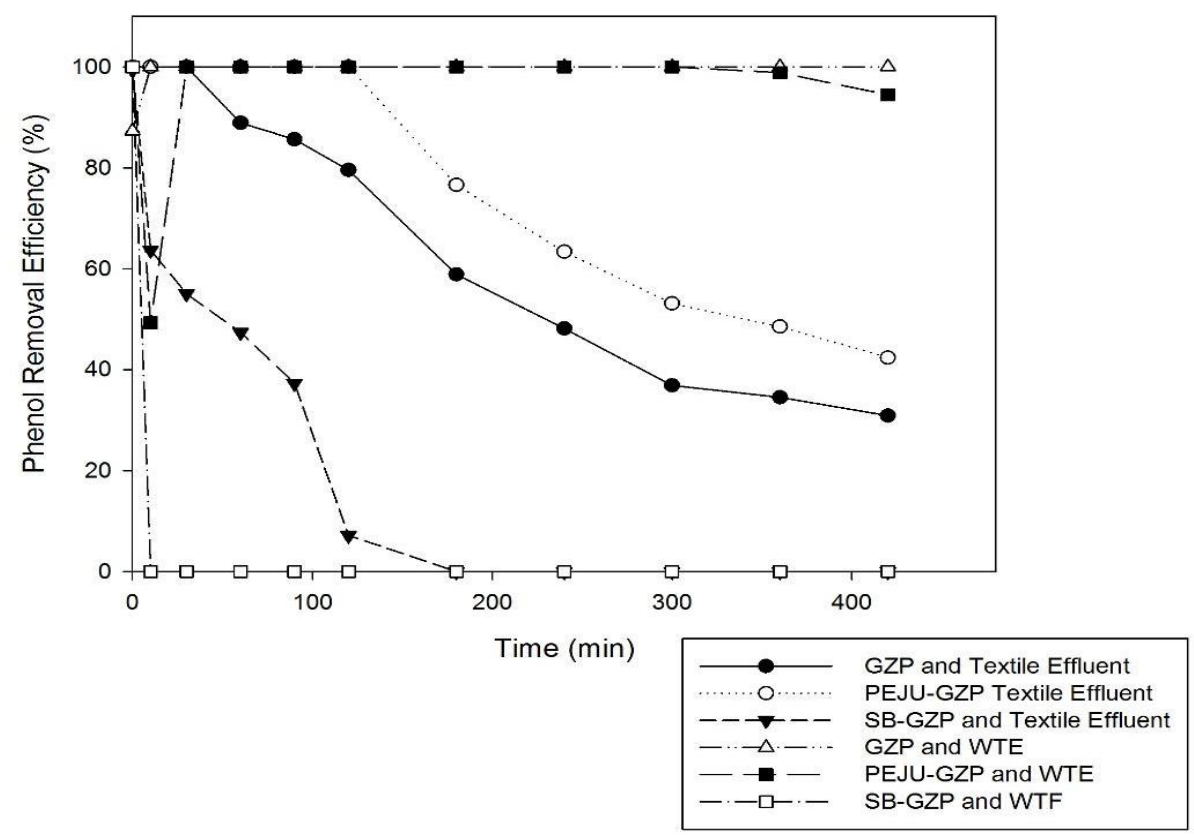

Figure 5. Phenol efficiency removal of green zucchini peroxidase (Cucurbita pepo, L.) and immobilized complexes in the effluent samples. Data were expressed in percentages. Circles represent the treatment on the textile effluent (a closed circle is free GZP and an open circle is the PEJU-GZP treatment). Downward-pointing triangles are SB-GZP treatments on textile effluent. Open triangles show the GZP capacity to treat effluent from WTS. Squares represent WTS effluent treatment by PEJU-GZP (closed) and by SBGZP (open).

Source: Prepared by the author. 
The immobilized complexes removed phenolic compounds and presented similar or superior performance in relation to the free enzyme. This can be explained by the inactivation and / or inhibition of the free enzyme caused by interactions between phenoxyl radicals or phenolic polymers produced during catalysis (Vineh et al., 2018).

Industrial effluents were degraded by all enzymatic forms. However, if we consider the time incubation period, the GZP immobilized form was more stable and continually removed phenols from complex mixtures over time. This is in agreement with Tatsumi et al. (1996), which used HRP immobilized on cellulose via oxidation through periodate and removed more than $80 \%$ phenol from aqueous solutions using continuous reactors. Figure 5 also demonstrates that the maximum reaction time for the phenol removal by the immobilized complexes was up to $30 \mathrm{~min}$. The free enzyme needed $90 \mathrm{~min}$ to achieve the maximum of phenol removal capacity.

The GZP complexes immobilized in PEJU-GO and SB are effective for the removal of phenols, with better performance (in the majority of the treatments) in the treatment with the free enzyme, after 10 min of reaction. Both materials (Enzyme and Support) are biodegradable and extracted in a sustainable manner, thus reducing the negative impact of chemical analyses on the environment and analytical laboratories.

\section{CONCLUSIONS}

This survey offers new alternatives for enzyme immobilization techniques using sources from crude extracts in a biodegradable carrier. The crude extract of green zucchini (Cucurbita pepo L.) showed a high content of peroxidase activity in different $\mathrm{pH}$ ranges, which makes this material a promising source for application in enzymatic technology. In addition, both sugarcane bagasse and arboreal cashew polysaccharide are sources of biotechnological application, especially as low-cost supports for peroxidase immobilization by physical adsorption and covalent binding. The enzymatic activity occurs in different reaction media, with a biodegradable and non-toxic material that is extracted in a sustainable way. In addition to these applications, the removal of phenolic compounds by the immobilized enzyme system showed high efficiency when using physical adsorption immobilization. This set of advantages reduces the negative impact of chemical waste on the environment and provides new analytical laboratory practices. The immobilized systems could be effectively operable and reliable and considered as a techno-economical and eco-friendly-oriented process for a large-scale application.

\section{ACKNOWLEDGEMENTS}

The authors are grateful to the Technological and Innovation Regional Centre, to the employees of DAIA Waste Treatment and to Alessandro de Paula Cardoso (engineer, Hering Company) for providing the effluent samples. They also thank the Coordination for the Improvement of Higher Level Personnel (CAPES), the PROBIP/UEG program and the National Scientific and Technological Council $(C N P q)$ for providing fellowship support.

\section{REFERENCES}

AHIRWAR, R.; SHARMA, J. G.; NAHAR, P.; KUMAR, S. Immobilization studies of cellulase on three engineered polymer surfaces. Biocatalysis and Agricultural Biotechnology, v. 11, p. 248-251, 2017. http://dx.doi.org/10.1016/j.bcab.2017.07.014

AKHTAR, M.; DING, R. Covalently cross-linked proteins \& polysaccharides: Formation, characterisation and potential applications. Current Opinion in Colloid \& Interface Science, v. 28, p. 31-36, 2017. https://doi.org/10.1016/j.cocis.2017.01.002 
BHUSHETTE, P. R.; ANNAPURE, U. S. Comparative study of Acacia nilotica exudate gum and Acacia Gum. International Journal of Biological Macromolecules, v. 102, p. 266271, 2017. http://dx.doi.org/10.1016/j.ijbiomac.2017.03.178

CALVINI, P.; GORASSINI, A.; LUCIANO, G.; FRANCESCHI, E. FTIR and WAXS analysis of periodate oxycellulose: Evidence for a cluster mechanism of oxidation. Vibrational Spectroscopy, v. 40, p. 177-183, 2006. https://doi.org/10.1016/j.vibspec.2005.08.004

CHOONG, G. Y. H.; FOCATTIS, D. S. A. A method for the determination and correction of the effect of thermal degradation on the viscoelastic properties of degradable polymers. Polymer Degradation and Stability, v. 130, p. 182-188, 2016. https://doi.org/10.1016/j.polymdegradstab.2016.06.018

DARKO, A.; CHAN, A. P. C.; OWUSU-MANU, D. G.; AMEYAW, E. E. Drivers for implementing green building technologies: An international survey of experts. Journal $\begin{array}{llllll}\text { of Cleaner Production, v. 145, p. 386-394, } 2017 . & \end{array}$ https://doi.org/10.1016/j.jclepro.2017.01.043

GOUVEIA, E. R.; NASCIMENTO, R. T.; SOUTO-MAIOR, A. M.; ROCHA, G. J. M. Validação de metodologia para caracterização química de bagaço de cana-de-açúcar. Química Nova, v. 32, n. 6, p. 1500-1503, 2009.

KALAIARASAN, E.; PALVANNAN, T. Removal of phenols from acidic environment by horseradish peroxidase (HRP): Aqueous thermostabilization of HRP by polysaccharide additives. Journal of the Taiwan Institute of Chemical Engineers, v. 11, p. 51-64, 2013. https://doi.org/10.1016/j.jtice.2013.07.003

KRISTIANSEN, K. A.; POTTHAST, A.; CHRISTENSEN, B. E. Periodate oxidation of polysaccharides for modification of chemical and physical properties. Carbohydrate Research, v. 345, p. 1264-1271, 2010. https://doi.org/10.1016/j.carres.2010.02.011

LIU, J. Z.; SONG, H. Y.; WENG, L. P.; JI, L. N. Increased thermostability and phenol removal efficiency by chemical modified horseradish peroxidase. Journal of Molecular Catalysis B: Enzymatic, v. 18, p. 225-232, 2002. https://doi.org/10.1016/S13811177(02)00100-5

NIU, J.; XU, J.; DAI, Y.; XU, J.; GUO, H.; SUN, K, LIU, R. Immobilization of horseradish peroxidase by electrospun fibrous membranes for adsorption and degradation of pentachlorophenol in water. Journal of Hazardous Materials, v. 246-247, p. 119-125, 2013. https://doi.org/10.1016/j.jhazmat.2012.12.023

RAMALHO, R. P. R. S.; SCALIZE, P. S.; CARAMORI, S. S. Peroxidase of Brazilian Cerrado grass as an alternative for agro industrial waste treatment. Revista Ambiente \& Água, v. 11, n. 1, p. 50-59, 2016. http://dx.doi.org/10.4136/ambi-agua.1735

SILVA T. M.; SOUZA, E. R. B., de PAUlA, J. A. M.; CARAMORI, S. S. Chemical characterization and biotechnological application of cashew tree polysaccharide of Brazilian Cerrado (Anacardium othonianum Rizz.), Anarcadiaceae. Revista Fronteiras: Journal of Social, Technological and Environmental Science, v. 6, n. 3, p. 230-246, 2017. http://dx.doi.org/10.21664/2238-8869.2017v6i3.p230-246

TATSUMI, K.; WADA, S.; ICHIKAWA, H. Removal of chlorophenols from wastewater by immobilized horseradish peroxidase. Biotechnology Bioengineering, v. 51; p. 126-30, 1996. https://doi.org/10.1002/(SICI)1097-0290(19960705)51:1\%3C126::AIDBIT15\%3E3.0.CO;2-O 
VIEIRA, I. C.; LUPETTI, K. O.; FATIBELLO-FILHO, O. Determination of paracetamol in pharmaceutical products using a carbon paste biosensor modified with crude extract of zucchini (Cucurbita pepo). Química Nova, v. 26, n. 1, p. 39-43, 2003. http://dx.doi.org/10.1590/S0100-40422003000100009

VINEH, M. B.; SABOURY, A. A.; POOSTCHI, A. A.; RASHID, A. M.; PARIVA, K. Stability and activity improvement of horseradish peroxidase by covalent immobilization on functionalized reduced graphene oxide and biodegradation of high phenol concentration. Journal of Biological Macromolecules, v. 106, p. 1314-1322, 2018. https://doi.org/10.1016/j.ijbiomac.2017.08.133 